\title{
Effect of Temperature And Number of Opaque Porcelain Firing on Bond Strength of Metal-Ceramic Fixed Partial Denture
}

\author{
Nidya P Sembiring ${ }^{1}$, Haslinda Z Tamin ${ }^{2}$, M Indra Nasution ${ }^{3}$ \\ ${ }^{1,2}$ Department of Prosthodontics, Faculty of Dentistry, Universitas Sumatera Utara, Medan \\ ${ }^{3}$ Department of Mechanical Engineering, Faculty of Engineering, Universitas Sumatera Utara, Medan
}

\begin{abstract}
Background: Metal-ceramic fixed partial denture has been widely used, as it provides both esthetics benefit of ceramic and strength of metal casting. The metal-ceramic bond is of fundamental importance to the success of restorations. Debonding of the ceramic from metal after the restoration has been permanently cemented creates an unacceptable blemish, and requires complete replacement of the restoration. Thus, the effects of metalceramic debonding are expensive and traumatic to the patient. The fracture failure rate of metal-ceramic restoration is 2\% - 8\% approximately. Porcelain-firing process is one of the factors relating to bond strength of metal-ceramic, including time, temperature, number of firing and atmospheric pressure.

Purpose: The purpose of this study was to determine effect of temperature and number of opaque porcelain firing on bond strength of metal-ceramic fixed partial denture.

Materials and Methods: The study involved 30 rectangular $(25 \times 3 \times 0.5 \mathrm{~mm}) \mathrm{Ni}$-Cr metal plates prepared based on ISO 9693 standard. VITA VMK Master opaque, dentin and enamel porcelain were applied on the center of metal plates in size of $8 \times 3 \times 1.1 \mathrm{~mm}$. The plates were then divided to six groups: Group I (firing temperature 950${ }^{\circ} \mathrm{C}, 1$ time firing); Group II (firing temperature $950^{\circ} \mathrm{C}$, 2 times firing); Group III (firing temperature $950^{\circ} \mathrm{C}, 3$ times firing); Group IV (firing temperature $975^{\circ} \mathrm{C}, 1$ time firing); Group V (firing temperature $975^{\circ} \mathrm{C}, 2$ times firing); Group VI (firing temperature $975^{\circ} \mathrm{C}, 3$ times firing). Bond strength measurement was performed by universal testing machine. The data was then analyzed by using one-way ANOVA test, $t$-test and Kruskal Wallis test.

Results: Three point bending test data shows highest bond strength (45.04 \pm 2.30$)$ in group with firing temperature of $975^{\circ} \mathrm{C}$ and 2 times firing, and lowest bond strength (24.5+2.29) in group with firing temperature of $950^{\circ} \mathrm{C}$ and 3 times firing. Statistical analysis shows significant influence of temperature and number of opaque porcelain firing on bond strength of metal-ceramic $(p<0.05)$.

Conclusion: Increasing the opaque porcelain firing temperature from $950^{\circ} \mathrm{C}$ to $975^{\circ} \mathrm{C}$ and number of firing from 1 to 2 times will increase bond strength of metal-ceramic, while increasing number of firing from 2 to 3 times will decrease bond strength of metal-ceramic.
\end{abstract}

Keywords: bond strength, metal-ceramic fixed partial denture, opaque porcelain firing temperature, number of opaque porcelain firing

\section{Introduction}

Metal-ceramic fixed partial denture is one of the most common restorations in recent decades, as it provides good esthetic and strength to accommodate masticatory force. It is comprised of two main components, i.e. metal coping and ceramic layer. Optimal bond of ceramic and metal is required for a long-term clinical success of the restoration. Debonding of the ceramic from metal after the restoration has been permanently cemented creates an unacceptable blemish, and requires complete replacement of the restoration. Thus, the effects of metal-ceramic debonding are expensive and traumatic to the patient. ${ }^{6,7}$ Fracture-failure rate of metalceramic crown is $2-8 \%$ approximately. ${ }^{3,8}$ Based on American Dental Association specification 38 (2000) and ISO standard 9693:2012, minimum bond strength of metal-ceramic is $25 \mathrm{MPa}$. Bonding mechanism of ceramic and metal is a result of chemical bond, mechanical interlocking, compressive forces and Van der Waals force. The chemical bond is the most important bond mechanism and occurs during firing process of porcelain. ${ }^{10-16}$. Factors of the porcelain firing process relating to bond quality are temperature, time, number of firing and atmospheric pressure. ${ }^{17-24}$ Attempt to obtain fine chemical bond includes following appropriate procedure of ceramic firing, but several studies have showed that slight change of firing number and temperature of opaque layer will increase bond strength of metal-ceramic. ${ }^{21}$ To facilitate fusion, McLean recommends baking a layer initially opaque at a temperature of $20^{\circ} \mathrm{C}$ higher than the temperature indicated by the manufacture for burning such porcelains. ${ }^{11,16}$ To achieve optimal contour, color and esthetic, repeated firing procedure is needed in construction of metal-ceramic restoration, but no scientific data were found on appropriate number of firing required to achieve a perfect restoration. ${ }^{19-20}$ Laboratory technicians frequently perform repeated firing caused by failure to obtain suitable shape and pattern of metal-ceramic restoration. ${ }^{25}$ 
Due to importance of metal-ceramic bond strength in long-term clinical success of restoration and difference of perspective in temperature and number of porcelain firing, this study was conducted to determine effect of temperature and number of opaque porcelain firing to obtain optimal bond strength in metal-ceramic fixed partial denture.

Fabrication of Metal Samples

\section{Materials And Methods}

Metal-ceramic samples were constructed according to ISO standard 9693;2012 (Figure 1). ${ }^{9,26}$
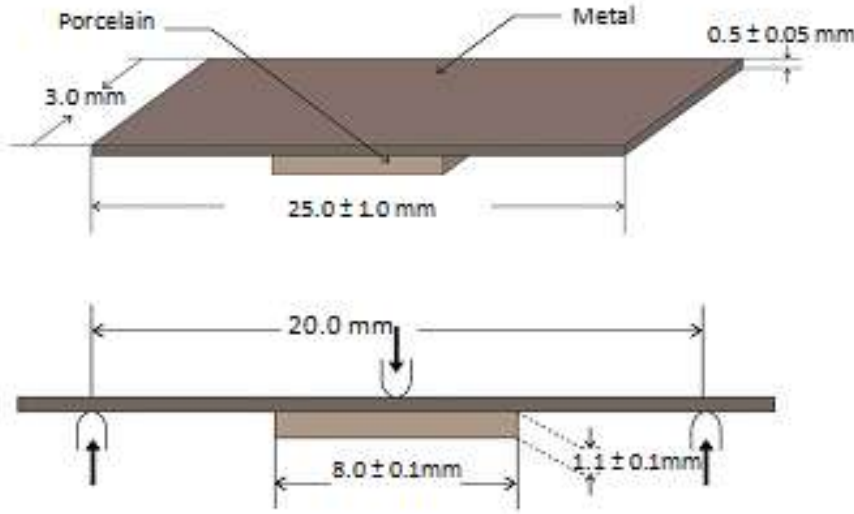

Figure 1. Schematic illustration of metal-ceramic samples

Thirty plates of rectangular $(25 \pm 1 \mathrm{~mm} \times 3 \pm 0.1 \mathrm{~mm} \times 0.5 \pm 0.05 \mathrm{~mm})$, Nickel-Chromium based metal alloy (Kera N, Germany, Ni 61.27\%, Cr 26.44\%, Mo 10.46\%, Mn 0.001\%, C 0.02\%), were made using prepared acrylic template. The acrylic template were sprued and invested with phosphate bonded investment material (Deyuan, China). Burned out procedure was then carried out in temperature of $1000^{\circ} \mathrm{C}$ (using burn our oven, K7, Manfredi, Italy). After burn out, casting were performed in $1450^{\circ} \mathrm{C}$ in centrifugal casting machine (Multihertz Century, Manfredi, Italy). Metal specimen were then cleaned of investment material and the edges were trimmed to obtain the size of $25 \times 3 \times 0.5 \mathrm{~mm}$, controlled by digital caliper (Mitutoya Co, Kawasaki, Japan). The metal specimen were then sandblasted with aluminum oxide $110 \mu \mathrm{m}$ for 10 seconds, from $2 \mathrm{~cm}$ distance, under 2 bar pressure and ultrasonically cleaned in distilled water for 10 minutes and dried at room temperature. The area for porcelain layer was marked by a sharp blade. Two perpendicular lines were made with $8.5 \mathrm{~mm}$ distance from each other and $4.25 \mathrm{~mm}$ distance from the center of the bar.

\section{Application of Ceramic Layer}

All samples were divided to 6 groups, based on temperature and number of opaque porcelain firing. Each group with 5 samples was oxidized in ceramic furnace (Ivoclar vivadent, Germany) in temperature of $980^{\circ} \mathrm{C}$. In group I and IV, opaque porcelain (VITA VMK Master) was applied together with thickness of $0.3 \mathrm{~mm}$ and fired once in temperature of $950^{\circ} \mathrm{C}$ (group I) and $975^{\circ} \mathrm{C}$ (group IV). In group II and V, number of firing was 2 times, in temperature of $950^{\circ} \mathrm{C}$ (group II) and $975^{\circ} \mathrm{C}$ (group V), with opaque porcelain applied separately in thickness of $0.1 \mathrm{~mm}$ and $0.2 \mathrm{~mm}$ gradually, in group III and VI, number of firing was 3 times, in temperature of $950^{\circ} \mathrm{C}$ (group III) and $975^{\circ} \mathrm{C}$ (group VI), with opaque porcelain applied separately in thickness of $0.1 \mathrm{~mm}$, $0.1 \mathrm{~mm}$, and $0.1 \mathrm{~mm}$ gradually. After adjusting and inspecting thickness of opaque porcelain with Boley Gauge (Dentaurum, Berlin Germany) and digital caliper (Mitutoyo Co, Kawasaki, Japan), dentin and enamel porcelain were applied and glazing was performed.

\section{Bond Strength Measurement}

Bond strength of metal-ceramic was determined according to ISO 9693, 2012 standards by three point bending test on universal testing machine (Sevopulser Model EHF-EB100KN-20L. Shimadzu. Japan). ${ }^{9,27}$ The specimens were placed with the ceramic facing down in the bending apparatus with rounded supporting rods $20 \mathrm{~mm}$ apart. The specimens were loaded in the center with a rounded bending piston; radius $1 \mathrm{~mm}$. Force was applied at a constant rate of $(1.0 \pm 0.5) \mathrm{mm} / \mathrm{min}$ and recorded until a disruption of the load-deflection curve occurred that indicated bond failure. The fracture force F (in newtons) was measured for specimen's failure by a debonding crack occurring at one end of the ceramic layer. The loads that resulted in bond failure were recorded digitally with computer using software (Figure 2). 


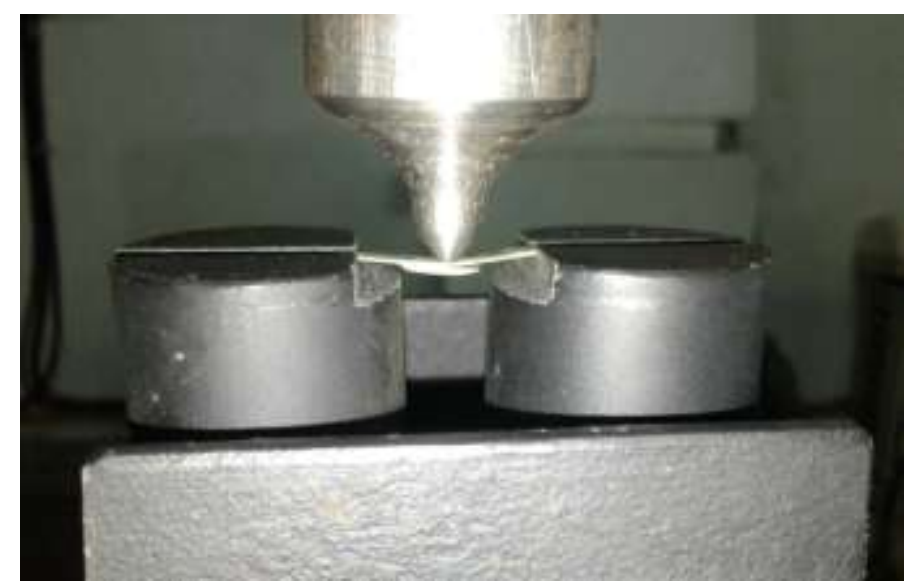

Figure 2. Three point bending test on universal testing machine

Bond strength was calculated with formula of $\tau=\mathrm{kxF}_{\text {fail, }}$ where $\tau$ is bond strength, reported in Megapascals (MPa). $\mathrm{K}$ is a constant, which is a function of the thickness of the metal sample and its modulus of elasticity. Bond strength value of six groups was analyzed by one-way ANOVA, t-test, and Kruskal Wallis test. Normal distribution data was tested by Shapiro-Wilk test. Homogeneity of variance was tested by Levene's test.

\section{Results}

Mean value of bond strength $(\tau)$ is measured in Megapascals (MPa) with deviation standard shown in Table 1. The highest mean value of bond strength is observed in group $\mathrm{V}$, with firing temperature of $975^{\circ} \mathrm{C}$ and 2 times firing $(45,04 \pm 2,30)$. The lowest mean value of bond strength is observed in group III, with firing temperature of $950^{\circ} \mathrm{C}$ and 3 times firing $(24,5 \pm 2,29)$.

Table 1. Mean value of metal-ceramic bond strength based on temperature and number of firing

\begin{tabular}{|c|c|c|c|c|c|c|}
\hline \multirow[t]{3}{*}{ Sample } & \multicolumn{6}{|c|}{ Bond Strength (MPa) } \\
\hline & \multicolumn{3}{|c|}{ Temperature $950{ }^{\circ} \mathrm{C}$} & \multicolumn{3}{|c|}{ Temperature $975^{\circ} \mathrm{C}$} \\
\hline & $\begin{array}{c}\text { Number } \\
\text { of } \\
\text { Firing } \\
1 \mathbf{x} \\
\text { (Group } \\
\text { I) }\end{array}$ & $\begin{array}{c}\text { Number of } \\
\text { Firing } \\
\mathbf{2} \text { x } \\
\text { (Group II) }\end{array}$ & $\begin{array}{l}\text { Number of } \\
\text { Firing } \\
\mathbf{3} \mathbf{x} \\
\text { (Group III) }\end{array}$ & $\begin{array}{c}\text { Number of } \\
\text { Firing } \\
1 \mathbf{x} \\
\text { (Group IV) }\end{array}$ & $\begin{array}{c}\text { Number } \\
\text { of Firing } \\
2 x \\
\text { (Group } \\
\text { V) }\end{array}$ & $\begin{array}{c}\text { Number of } \\
\text { Firing } \\
\mathbf{3 x} \\
\text { (Group VI) }\end{array}$ \\
\hline 1 & 29 & 38,9 & 26 & 37 & 42,8 & 27,8 \\
\hline 2 & 37 & 35 & 22 & 37 & 46 & 26 \\
\hline 3 & 31,5 & 37 & 26 & 35 & 42,8 & 29,7 \\
\hline 4 & 31,5 & 40,8 & 22 & 35,6 & 48,2 & 34,5 \\
\hline 5 & 35 & 35 & 26,5 & 38,9 & 45,4 & 29,7 \\
\hline $\begin{array}{c}\text { Mean } \\
\pm \text { SD }\end{array}$ & $\begin{array}{c}(32,8 \pm \\
3,17) \\
\end{array}$ & $(37,34 \pm 2,52)$ & $\begin{array}{c}(24,5 \pm \\
2,29) \\
\end{array}$ & $\begin{array}{c}(36,7 \pm \\
1,51) \\
\end{array}$ & $\begin{array}{c}(45,04 \pm \\
2,30) \\
\end{array}$ & $(29,54 \pm 3,17)$ \\
\hline
\end{tabular}

Analysis result of independent t-test shows significant effect of firing temperature of $950^{\circ} \mathrm{C}$ and $975^{\circ} \mathrm{C}$ and single firing on bond strength of metal-ceramic $(p=0.038)$. There is a significant effect of firing temperature of $950^{\circ} \mathrm{C}$ and $975^{\circ} \mathrm{C}$ and 2 times firing on bond strength of metal-ceramic $(p=0.001)$. There is a significant effect of firing temperature of $950^{\circ} \mathrm{C}$ and $975^{\circ} \mathrm{C}$ and 3 times firing on bond strength of metal-ceramic $(p=0.025)($ Table 2).

Table 2. Effect of temperature on bond strength of metal-ceramic

\begin{tabular}{|c|c|c|c|}
\hline \multicolumn{4}{|c|}{ Bond Strength of Metal-Ceramic, Mean \pm (SD), (Mpa) } \\
\hline $\begin{array}{c}\text { Number of } \\
\text { Firing }\end{array}$ & $\begin{array}{c}\text { Firing } \\
\text { Temperature } \mathbf{9 5 0}{ }^{\circ} \mathbf{C}\end{array}$ & $\begin{array}{c}\text { Firing } \\
\text { Temperature } \mathbf{9 7 5}{ }^{\circ} \mathbf{C}\end{array}$ & $\mathbf{p}$ \\
\hline 1 Time & $32,8 \pm 3,17$ & $36,7 \pm 1,51$ & $0,038^{*}$ \\
\hline 2 Times & $37,34 \pm 2,52$ & $45,04 \pm 2,30$ & $0,001^{*}$ \\
\hline 3 Times & $24,5 \pm 2,29$ & $29,54 \pm 3,17$ & $0,025^{*}$ \\
\hline Mean \pm (SD) & $31,55 \pm 6,04$ & $37,09 \pm 6,93$ & $0,027^{*}$ \\
\hline
\end{tabular}

Kruskal Wallis test shows significant effect of number of opaque porcelain firing, in temperature of $950^{\circ} \mathrm{C}$ on bond strength of metal-ceramic $(p=0,004)$ (Table 3). 
Table 3. Effect of number of opaque porcelain firing in temperature of $950^{\circ} \mathrm{C}$ on bond strength of metalceramic

\begin{tabular}{|c|c|c|c|}
\hline $\begin{array}{c}\text { Firing } \\
\text { Temperature }\end{array}$ & $\begin{array}{c}\text { Number of } \\
\text { Firing }\end{array}$ & $\begin{array}{c}\text { Bond Strength of } \\
\text { Metal-Ceramic, } \\
\text { Mean } \pm \text { (SD) } \\
\text { (MPa) }\end{array}$ & \multirow{2}{*}{0} \\
\hline \multirow{2}{*}{$950{ }^{\circ} \mathrm{C}$} & $\begin{array}{c}\text { Group I } \\
(1 \text { Time) }\end{array}$ & $32,8 \pm 3,17$ & \multirow{2}{*}{$0,004^{*}$} \\
\cline { 2 - 3 } & $\begin{array}{c}\text { Group II } \\
\text { (2 Times) }\end{array}$ & $37,34 \pm 2,52$ & \\
\cline { 2 - 4 } & $\begin{array}{c}\text { Group III } \\
\text { (3 Times) }\end{array}$ & $24,5 \pm 2,29$ & \\
\hline
\end{tabular}

One-Way Anova test shows significant effect of number of opaque porcelain firing in temperature of $975^{\circ} \mathrm{C}$ on bond strength of metal-ceramic $(p=0,001)$ (Table 4$)$.

Table 4. Effect of number of opaque porcelain firing in firing temperature of $975^{\circ} \mathrm{C}$ on bond strength of metalceramic

\begin{tabular}{|c|c|c|c|}
\hline $\begin{array}{c}\text { Firing } \\
\text { Temperature }\end{array}$ & $\begin{array}{l}\text { Number of } \\
\text { Firing }\end{array}$ & $\begin{array}{c}\text { Bond Strength of } \\
\text { Metal-Ceramic, } \\
\text { Mean } \pm(\text { SD) } \\
(\mathrm{MPa}) \\
\end{array}$ & $p$ \\
\hline \multirow[t]{3}{*}{$975^{\circ} \mathrm{C}$} & $\begin{array}{l}\text { Group IV } \\
\text { (1 Time) }\end{array}$ & $\begin{array}{c}36,7 \pm \\
1,51\end{array}$ & \multirow[t]{3}{*}{$0,001^{3}$} \\
\hline & $\begin{array}{l}\text { Group V } \\
\text { (2 Times) }\end{array}$ & $45,04 \pm 2,30$ & \\
\hline & $\begin{array}{l}\text { Group VI } \\
\text { (3 Times) }\end{array}$ & $29,54 \pm 3,17$ & \\
\hline
\end{tabular}

\section{Discussion}

This study aimed to determine effect of temperature and number of opaque porcelain firing on bond strength of metal-ceramic. Results show that temperature and number of opaque porcelain firing have significant effect on bond strength of metal-ceramic. Almost all samples tested reveal bond strength higher than $25 \mathrm{MPa}$, the minimal value of bond strength according to ISO 9693:2012 standard. Firing temperatures of opaque porcelain in this study are $950^{\circ} \mathrm{C}$ as suggested by factory and $975^{\circ} \mathrm{C}$ as trial. Bond strength measurement results of group with firing temperature higher than that of manufacturer's recommendation $\left(975^{\circ} \mathrm{C}\right)$ is $(37.09 \pm 6.93)$, statistically higher than that of groups with temperature of $950^{\circ} \mathrm{C}$, which is $(31.55 \pm 6.04)$. This temperature increasing technique is based on assumption that increase electron transfer occurs between ceramic and metal oxide, which will increase its bond strength. In high temperature, fuse of porcelain to metal surface will improve, increasing interaction of atoms between metal surface and ceramic and its penetration to the irregular surface of metal. ${ }^{26-28}$ Vasconcellos et al. stated that increasing of the opaque layer firing temperature significantly increased the flexural bond strength values. Opaque porcelain is the first layer applied and performs two major functions: it masks the color of the alloy, and it is responsible for the metal-ceramic bond. ${ }^{28}$ Wetting of metal surface by porcelain occurred during firing of opaque porcelain. Porcelain melted and chemical bond occurred between metal and porcelain. The chemical bond is the most important bond mechanism and occurs during firing process of porcelain, where atoms of metal, ceramic molecule and oxide atom condensate. $^{29}$

Porcelain firing to construct metal-ceramic restoration, generally consists of opaque, dentin, enamel firing and glazing. Repeated firing procedure was performed to achieve better contour, color and esthetic, but there is no scientific data regarding appropriate number of firing cycle to achieve a perfect restoration. ${ }^{19,20,30,31}$ Laboratory technicians perform repeated firing due to failure to obtain appropriate shape and pattern of metalceramic restoration. ${ }^{25,28}$ In this study, results show significant effect of number of opaque porcelain firing on bond strength of metal-ceramic $(p<0.05)$. Data of groups with firing temperature of $950^{\circ} \mathrm{C}$ show that single firing of opaque porcelain decreased bond strength of metal-ceramic $(32.8 \pm 3.17)$, which increased with 2 times firing $(37.34 \pm 2.52)$. But mean value of metal-ceramic bond strength decreased with 3 times firing $(24.5 \pm$ 2.29). Data of groups with firing temperature of $975^{\circ} \mathrm{C}$ show that single firing of opaque porcelain decreased bond strength of metal-ceramic $(36.7 \pm 1.51)$, which increased with 2 times firing $(45.04 \pm 2.30)$. But mean value of metal-ceramic bond strength decreased with 3 times firing $(29.54 \pm 3.17)$. The results show that number of opaque porcelain firing that is too scarce or frequent will decrease bond strength of metal-ceramic. Repeated firing of porcelain would theoretically decreased metal-ceramic compatibility and a subsequent decrease in bond strength. Ren et al. stated that thermal coefficient of expansion for ceramic will increase on repeated firing. In repeated firing, formation of oxide layer will also be difficult to control. Rokni and Baradaran stated than formation of excessive oxide layer was found to be enhanced by repeated firings. In this study, in groups with 1 
time firing, opaque porcelain was applied altogether in thickness of $0.3 \mathrm{~mm}$ to the surface of metal. In groups with 2 times firing, opaque porcelain was applied gradually in thickness of $0.1 \mathrm{~mm}$, and followed by thickness $0.2 \mathrm{~mm}$. In groups with 3 times firing, opaque porcelain was gradually applied in thickness of $0.1 \mathrm{~mm}, 0.1 \mathrm{~mm}$ and $0.1 \mathrm{~mm}$. Bond strength value of metal-ceramic in opaque porcelain with 1 time firing is lower than 2 times firing, which might be due to its $0.3 \mathrm{~mm}$ thickness, while 2 times firing opaque porcelain was fired twice with thickness of $0.1 \mathrm{~mm}$, followed by thickness $0.2 \mathrm{~mm}$ and groups with three times firing was coated first with 0.1 $\mathrm{mm}$ thickness of opaque porcelain, repeatedly. The study also shows that surface of opaque porcelain fired altogether in thickness of $0.3 \mathrm{~mm}$ could crack easily, while surface fired first with $0.1 \mathrm{~mm}$ thickness of opaque porcelain displayed smoother and less easily cracked surface, thus showing its effect on bond strength of metalceramic.

\section{Conclusion}

Based on the result, it is concluded that temperature and number of opaque porcelain firing significantly affect the bond strength value of metal-ceramic. Firing temperature of $975^{\circ} \mathrm{C}$ with 2 times firing results in highest bond strength that exceeds ISO 9693:2012 standard of 25MPa, thus is recommended as guidance in fabrication of metal-ceramic fixed partial denture to create optimal bond strength, which lead to long-term clinical success of metal-ceramic fixed partial denture.

\section{References}

[1]. Shillingburg, HT, Sather, DA, Wilson, EL, Cain, JR, Mitchell, DL, Blanco, LJ, Kessler, JC. Fundamental of fixed prosthodontics, $4^{\text {th }}$ edn. USA: Quintessence books; 2012, p455-483.

[2]. Ahmadzadeh A, Neshati A, Mousavi A, Epackchi S, Dabaghi TF, Sarbazi AH. A comparison between shear bond strength of VMK master porcelain with three base-metal alloys (Ni-Cr-T3, verabond, super cast) and one noble alloy (X-33) in metal-ceramic restorations. J Dent Shiraz Univ med Sci 2013; 14(4): 191-196.

[3]. Zhang S, Yushu DW, Liu BX, Sun B, Yan CZ, Hao L, Wei QS, Shi YS. Effect of firing temperature on the metal to ceramic bond strength of a porcelain fused to metal restoration of a Co-Cr alloy by means of selective laser melting (SLM). Lasers in Eng 2015; 31: 195-209.

[4]. Smith BGN. Planning and making crowns and bridges (Dentistry in practice). London: Martin dunitz Ltd; 1987 , p130-185.

[5]. Qiu J, Yu WQ, Zhang FQ, Smales RJ, Zhang YL, Lu CH. Corrosion behavior and surface analysis of a Co-Cr and two Ni-Cr dental alloys before and after simulated porcelain firing. Eur J Oral Sci 2011; 119: 93-101

[6]. Powers JM, Wataha JC. Dental Materials: Properties and Manipulation. $9^{\text {th }}$ edn. St. Louis, Missouri: Elsevier; 2008.

[7]. Hatrick CD, Eakle WS, Bird WF. Dental Materials: clinical applications for dental assistants and dental hygienists. $2^{\text {nd }}$ edn. St. Louis, Missouri: Elsevier; 2011:100-26.

[8]. Goodacre CJ, Bernal G, Rungcharassaeng K, Kan JYK. Clinical complications in fixed prosthodontics. J Prosthet Dent 2003; 90: 31-41.

[9]. Ren XW, Zeng L, Wei ZM, Xin XZ, Wei B. Effects of multiple firings on metal-ceramic bond strength of Co-Cr alloy fabricated by selective laser melting. Journal of prosthetic dentistry 2016; 115: 109-114.

[10]. Khmaj, MR. Comparison of metal-ceramic bond strengths of four noble alloys using press-on-metal (PoM) and conventional layering techniques. Masters thesis, The Ohio States University; 2012.

[11]. Olivieri KAN, Neisser MP, Bottino MA, Miranda ME. Bond characteristics of porcelain fused to cast and milled titanium. Braz J Oral sci 2005; 4(15): 923-8.

[12]. Mutawa NJ, Sato T, Shiozawa I, Hasegawa S, Miura H. A study of the bond strength and color of ultralow-fusing porcelain. The International Journal of Prosthodontics 2000; 13(2): 159-64.

[13]. Al Amri MD, Hammad IA. Shear bond strength of two forms of opaque porcelain to the metal substructure. King Saud University Journal of Dental Sciences 2012; 3: 41-8.

[14]. Van noort R. Introduction to dental material. $3^{\text {rd }}$ edn. London: Elsevier; 2007, p237-54.

[15]. Hadi A, Massoumi F, Mossaei A. Effect of opaque porcelain thickness on bond strength of porcelain to Ni-Cr alloys. Journal of Dental School 2016; 34(2): 72-81.

[16]. Giannarachis C, Marmandiu C, Vasilescu VG, Vasilescu E, Patrascu I. Studies on the importance of metal-ceramic bond in merging ceramic mass on metal component. Fascicula 2013; 17(2): 5-12.

[17]. Cheung KC, Darvell BW. Sintering of dental porcelain: effect of time and temperature on appearance and porosity. Dental materials 2002; 18: 163-73.

[18]. Gupta KL, Neeraj N. Evaluation of the bond strength of porcelain to non precious metal copings under different firing atmospheres. Indian Journal of Dental Sciences $2011 ; 2(3): 1-4$

[19]. Rayyan MM. Effect of multiple firing cycles on the shear bond strength and failure mode between veneering ceramic and zirconia cores. Egyptian Dental Journal 2014; 60(3): 3325-33.

[20]. Sayed NM. Shear bond strength and failure mode between veneering ceramic and metal cores after multiple firing cycles. Egyptian Dental Journal 2015; 61: 659-66.

[21]. Vasconcellos LG, Buso L, Lombardo GH, Souza RO, Nogueira Jr L, Bottino MA, et al. Opaque layer firing temperature and aging effect on the flexural strength of ceramic fused to cobalt-chromium alloy. Journal of prosthodontics 2010; 19: 471-477.

[22]. Monika S, Yashpcal S, Arvind T, Saumyendra VS, Bikramjit B, Suresh C. Effect of firing temperatures on interface of porcelain fused to metal restorations: An in vitro study. Indian J Stomatol 2011; 2(4): 222-26.

[23]. Ali RT, Ismail K, Serdar P, Meral AM, Mehmet D. The effect of repeated porcelain firings on corrosion resistance of different dental alloys. J Adv Prosthodont 2013; 5: 44-50.

[24]. Tuncdemir AR, Karahan I, Polat S, Malkoc MA, Dalkiz M. The effect of repeated porcelain firings on corrosion resistance of different dental alloys. J Adv Prosthodont 2013; 5: 44-50.

[25]. Ghanbarzadeh J, MR Sabooni, N Amiri T. The influence of repeated firing on color stability of two porcelain types. J Med Sci 2008; 8(1): 77-80. 
[26]. Hong JT, Shin SY. A comparative study on the bond strength of porcelain to the millingable Pd-Ag alloy. J Adv Prosthodont 2014; 6: $372-8$.

[27]. Henriques, BAPC. Bond strength enhancement of metal-ceramic dental restoration by FGM design. PhD thesis, Universidade do Minho escola de Engenharia; 2012 .

[28]. Rosenstiel SF, Land MF, Fujimoto J. Contemporary fixed prosthodontics. $4^{\text {th }}$ ed. St Louis: Elsevier, 2006: 609-39.

[29]. Rokni SR, Baradaran H. The effect of oxide layer thickness on bond strength of porcelain to Ni-Cr alloy. Journal of Mashhad Dental School 2007; 31: 17-21

[30]. Jalali H, Bahrani Z. A comparison review of reliability of multiple firing techniques on the microtensile bond strength in lithium disilicate bases ceramics: A review study. Bulletin of Environment, Pharmacology and Life Sciences 2015; 4(7): 192-6.

[31]. Zakaria MR, Jassim HH. Evaluation of the effects of porcelain firing cycles on the marginal fit changes of porcelain-fused-to-metal crowns constructed utilizing two different marginal designs and alloys. Al-Rafidain Dent J 2003; 3(3): 13-19. 